\title{
Why Did Poland Choose The F-16?
}

\author{
Col. Barre R. Seguin *
}

\begin{abstract}
This essay provides a comprehensive synthesis of the Polish military's fighter aircraft selection process, assesses the dominant issues, and answers the question, "Why did Poland choose the F-16?" It begins with a brief examination of Poland's military aircraft status and military aircraft industrial production capability from approximately 1990 to 2002, its requirements for an advanced fighter aircraft, and Poland's military hardware procurement and acquisition processes. Analysis then turns to acquisition reforms associated with the F16 decision, the institutional structure for purchasing military aircraft, the mechanics of the F-16 decision, and who ultimately made the decision. Given the centrality to the decision process, a capabilities comparison of the three competitors - the Lockheed Martin F-16, Saab/BAE Systems JAS-39 Gripen, and the Dassault Mirage 2000-5 Mk II-is offered and interoperability considerations addressed. This study then outlines the financial construction of the three bids, to include economic issues and pressures from the U.S., French, and Swedish governments and industry, and an in-depth analysis of industrial offsets. Lastly, it will examine political issues associated with the F-16 purchase.
\end{abstract}

Keywords: Poland; Lockheed Martin F-16; Saab/BAE Systems JAS-39 Gripen; Dassault Mirage 2000-5 Mk II; acquisition; technical comparison; financing; offset; U.S.-Polish relationship; fighter competition

\section{Introduction}

On 27 December 2002, Poland's Minister of Defense Jerzy Szmajdzinski announced Poland's decision to purchase forty-eight state-of-the art F-16 fighter aircraft from the U.S. aerospace firm Lockheed Martin. The "deal of the century," as Christopher R. Hill, U.S. Ambassador to Poland, characterized it, was sealed on 18 April 2003 with the signing of the contract by Polish and U.S. officials, and Lockheed Martin senior executives. ${ }^{1}$ The contracts involved three separate, but related, agreements: the sale of forty-eight F-16 52+;

* Barre R. Seguin is a Colonel in the United States Air Force, and is currently serving as a Special Assistant to the Commander, U.S. European Command, and Supreme Allied Commander, Europe, at Supreme Headquarters Allied Powers, Europe, in Mons, Belgium. Prior to his current assignments, Col. Seguin was a Senior Fellow at the George C. Marshall European Center for Security Studies in Garmisch-Partenkirchen, Germany. He is a combat mission commander with over 3000 flying hours in the F-16 and T-38.

1 John Tagliabue, "Lockheed Wins Huge Sale to Poland With Complex Deal," The New York Times (19 April 2003), C4. 
an offset package to invest in Poland over a 10 year period $;^{2}$ and favorable U.S. government-backed low-interest financing. ${ }^{3}$

Poland's decision to purchase the F-16 had interwoven capability, interoperability, economic, and political dimensions. The main issues that drove Poland's decision to purchase the F-16 included a technical analysis of competing aircraft, price, financing, offsets, and politics. The mass media and the business community, particularly in Poland, portrayed the deal primarily in economic terms, emphasizing the favorable financing offered by the U.S. and the unprecedented offset agreement. Polish officials and politicians painted a picture of a more balanced decision for their constituents, one that emphasized price, tactical, and operational criteria over offsets. Academics, pundits, and officials from the losing bidders, Dassault and Saab/BAE, weighed politics more heavily in their assessments of the decision process than aircraft capabilities or economics.

\section{Aircraft Production and Requirements}

When the Iron Curtain fell, Poland found itself with a fairly robust air force, but one that was beginning to erode. The country had a total of approximately 800 combat aircraft in $1990{ }^{4}$ This number decreased rapidly to 300 in 1998 , with a target of about 100 slated for 2002. ${ }^{5}$ The deteriorating inventory of fighter aircraft and the target plan of 100 influenced the mindset of Polish decision-makers leading up to the decision at the end of 2002 to purchase the F-16. Of the fighter aircraft Poland had in its inventory in 1990, only a handful had any reasonably modern combat capability: twenty-two MiG-29s and nearly $100 \mathrm{Su}-$ $22 s^{6}$ In addition to limited numbers of combat aircraft, Polish aircraft production capacity was in a dismal state. A robust aeronautical industrial base from which to produce a fourth-generation fighter simply did not exist in Poland.

Despite Poland's limited production capability, a strong internal rationale existed to justify a costly investment in a fighter aircraft. As a matter of national pride, Poland-a nation that joined NATO in 1999-no longer wanted to feel like a second-class relative to other Western air forces. It also wanted the purchase to reflect the country's recent military transformation. ${ }^{7}$ Moreover, Poland not only needed interoperable aircraft that met NATO standards, ${ }^{8}$ it had to be capable of committing forty-eight modern jet fighters to NATO Reaction Forces (NRF). ${ }^{9}$ Existing Polish fighters were costly to maintain and oper-

2 Offset is a contracting and acquisition term of art meaning an agreement between two governments or a government and a foreign supplier to invest in the country's industrial or educational base.

3 Tagliabue, "Lockheed Wins Huge Sale."

4 Jeffrey Simon, Poland and NATO (Lanham, MD: Rowman \& Littlefield Publishers, Inc., 2004), 90.

5 Ibid.

6 Ibid.

7 B. Glowacki and G. Sobzack, "Poland Opts for F-16s," Flug Revue (March 2003); available at www.flug-revue.rotor.com/FRhft/FRH0303/fr0303a.htm.

8 Christopher Bollyn, "Why Eastern Europe Supported War," Rumor Mill News Agents Forum, available at www.thetruthseeker.co.uk/article.asp?ID $=746$.

9 Simon, Poland and NATO, 90. 
ate, lacked NATO interoperability, and were insufficient to meet the NRF commitment. Polish officials felt that equipment modernization, and the F-16 in particular, bolstered Poland's standing in NATO and aided in the professionalization of its military. ${ }^{10}$

As eloquently as proponents justified Poland's need for a modern, fourth-generation multi-role fighter, opponents voiced their objections just as vehemently. In August 2002, Andrzej Karkoszka, the former defense secretary, published an article entitled "Fly or Think?" An early supporter of Poland acquiring modern fighter aircraft, Karkoszka performed an about-face and argued that the former threat from the East had been superseded by a terrorist threat that did not justify a large investment in expensive new jet fighters. Instead, Karkoszka advocated buying used fighters. His opinion was rebuffed by Deputy Defense Minister Zemke in an article entitled "Thinking and Flying." In the article, Zemke demonstrated that used fighters would cost half as much as new fighters but would have less than half the life expectancy in terms of flying hours and would not be nearly as technologically advanced. Instead, Zemke supported a plan to purchase new fighters with a favorable contract that delayed the brunt of the financial liabilities until after 2009, when 1970s-era loans would be paid. ${ }^{11}$ With the requirement for modern jet fighter aircraft established, Poland embarked on an acquisition and procurement process that was initially riddled with corruption.

\section{Acquisition Process}

To fully grasp how the final decision was made to select the F-16, the process leading to the selection of a final bid must first be analyzed. Such an analysis must begin with an understanding of Poland's acquisition process. In Poland, public and social institutions, including the Ministry of Defense, Sejm, Senate, ${ }^{12}$ Commission of National Defense, the Highest Chamber of Control (Najwyzsza Izba Kontroli, or NIK), and the mass media all influence military expenditures. The Polish Armed Forces articulates and justifies requirements. Parliament creates the budget, which is then subject to public scrutiny via the published diary of bills. The budget is controlled by the Department of Control in the Ministry of Defense, and the execution of the budget was examined by the NIK and ana-

10 Andrew A. Michta, "Modernizing the Polish Military," Defence Studies 2:2 (Summer 2002): 44.

11 Simon, Poland and NATO, 135.

12 Poland is a democracy with a president as head of state. Its constitution dates from 1997. The president is elected by popular vote every five years. The Council of Ministers, or cabinet, is led by a prime minister. The prime minister proposes and the president appoints the cabinet. The cabinet is typically appointed from the majority coalition in the bicameral judicial lower house (the Sejm). Polish voters elect a bicameral parliament consisting of a 460-member lower house Sejm and a 100-member Senate (Senat). The Sejm is elected under proportional representation according to the d'Hondt method. The Senate is elected under a rare plurality bloc voting method where several candidates with the highest support are elected from each constituency. With the exception of ethnic minority parties, only candidates of political parties receiving at least 5 percent of the total national vote can enter the Sejm. When sitting in joint session, members of the Sejm and Senate form the National Assembly (the Zgromadzenie Narodowe). 
lyzed by Parliament. ${ }^{13}$ Despite such apparently extensive oversight, Poland's acquisition processes preceding the F-16 tender lacked transparency and were plagued by corruption.

Initially, Polish officials insisted that the process for selecting a fourth-generation fighter aircraft be transparent, credible, and comprehensively rigorous. An interministerial committee was established by Deputy Defense Minister Szeremietiew on 5 March 2001, to outline the path that the acquisition process should follow. Defense Minister Komorowski weighed in and set up an additional bidding team of experts headed by Colonel Wlodzimierz Plach, the deputy director of the Armed Forces Supplies Department. Komorowski was so concerned with transparency that he charged the bidding commission to not rule out participation by opposition forces. ${ }^{14}$

Plach's team, given their expertise, would evaluate the combat capabilities and technical aspects of each competing fighter, while Szeremietiew's interministerial group would make the ultimate decision. Referring to the purchase, Deputy Prime Minister and Finance Minister Janusz Steinhoff stated, "One of the most important elements that would affect the final choice would be terms of offsetting the purchase with orders placed in Polish plants." ${ }^{15}$ This largely set the priorities and ground rules for the competing bids. 10 September 2001 was set as the date to announce the winning bid, with 14 September 2001 as the contract signing date. These dates, however, proved to be overly optimistic.

In the midst of the aggressive fighter aircraft procurement schedule, a corruption scandal related to military procurement exploded within the Ministry of Defense and disrupted the decision timeline. Prime Minister Buzek suspended Deputy Defense Minister Szeremietiew on 7 July 2001 and appointed a special commission to investigate suspect procurement orders within the ministry. The suspension centered around Szeremietiew's close relationship with Zbigniew Farmus, who was arrested on 10 July and accused of selling inside information to bidding competitors and soliciting bribes in exchange for contracts. ${ }^{16}$

In conjunction with developments in the case, Prime Minister Buzek charged Deputy Prime Minister Janusz Steinhoff and Defense Minister Komorowski with supervising all public tenders for military equipment. The bid selection process for the multipurpose fighter jet was immediately delayed, and personnel shake-ups followed. Brigadier General Roman Baszuk, the air force's chief of logistics command, was named to replace Szeremietiew as chair of the mixed bid commission. ${ }^{17}$ In mid-November 2002, the Tender Commission opened bids and the process of technical analysis began. Deliberations were secret, but remained under the auspices of the Military Information Services (Wojskowe Sluzby Informacyjne, or WSI). ${ }^{18}$ Due to the secrecy of the deliberations, little was published on the details of how the decision was reached.

What was known about the selection process is that the decision was made by the Tender Commission, composed of a twenty-three-person evaluation committee. A somewhat

${ }^{13}$ Ministry of National Defense, Republic of Poland, Basic Information on the MoND Budget for 2001-2006; available at www.wp.mil.pl/en/strona/126.

${ }^{14}$ Simon, Poland and NATO, 117.

15 Ibid, 118.

16 Simon, Poland and NATO, 121.

17 Ibid.

18 Ibid, 135. 
complicated points award system was used, consisting of forty-five points for the best price, twenty points for operational suitability, twenty points for compliance with tactical and technical requirements, and fifteen points for offsets. Although the actual results were not published, speculation has it that the F-16 was awarded ninety-six out of a possible one hundred points, ninety-three for the Saab/BAE JAS-39 Gripen, and a slightly lower score for the Dassault Mirage 2000-5 Mk II. ${ }^{19}$ In spite of the secret deliberations, Prime Minister Miller declared that the "entire, complex process of choosing the aircraft took place under conditions of complete transparency and fairness, while preserving the objectivity that is particularly necessary in analytical work." ${ }^{20}$ The ratings, however, do not tell the whole story of why the Poles chose the F-16.

\section{Performance and Interoperability}

In analyzing why the Polish military chose the F-16, a brief analysis and comparison of the capabilities of the three contending aircraft is required. The three final competitors for the Polish tender were the Lockheed Martin F-16C/D Block 52+, Saab/BAE Systems JAS-39 Gripen, and the Dassault Mirage 2000-5 Mk II. The actual details of what Saab/BAE Systems and Dassault offered are not public. Therefore, some of the capabilities comparisons are based on the assumption, gleaned from several sources, that the competitors offered the top-of-the-line capabilities then available. A broad-brush performance comparison of the three fighter aircraft is presented in Table 1.

Table 1: Fighter Aircraft Performance Comparison ${ }^{21}$

\begin{tabular}{lccc}
\hline & F-16C/D 52+ & Mirage 2000-5 MkII & JAS-39 Gripen \\
\hline $\begin{array}{l}\text { Max level speed } \\
\text { (at altitude) }\end{array}$ & Above 2.0 mach & $2.2 \mathrm{mach}$ & $\begin{array}{c}\text { Supersonic at all } \\
\text { altitudes }\end{array}$ \\
\hline $\begin{array}{l}\text { Max level speed } \\
\text { (sea level) }\end{array}$ & $>1.0$ mach & $1.2 \mathrm{mach}$ & $>1.0$ mach \\
\hline Service ceiling & $>15,240 \mathrm{~m}$ & $18,290 \mathrm{~m}$ & Not available \\
\hline $\begin{array}{l}\text { Range (hi-low-hi } \\
\text { attack profile) }\end{array}$ & 676 nautical miles & 650 nautical miles & 432 nautical miles \\
\hline g-limits & +9.0 & $+9.0 /-3.2$ & +9.0 \\
\hline $\begin{array}{l}\text { Max external stores } \\
\text { load }\end{array}$ & $7,226 \mathrm{~kg}$ & $6,300 \mathrm{~kg}$ & Approx $6,000 \mathrm{~kg}$ \\
\hline
\end{tabular}

19 Glowacki and Sobzack, "Poland Opts for F-16s."

20 The Chancellery of the Prime Minister, Republic of Poland, "Signing of Agreement for Delivery of F-16 Aircraft," 18 April 2003; available at http://www.kprm.gov.pl/archiwum/english/ 2130 5889.htm.

21 Paul Jackson, Kenneth Munson, and Lindsay Peacock, eds., Jane's All the World's Aircraft (Surrey, UK: Jane's Information Group Limited, 2002), 118, 440, 651. 
Poland considered the following missions as part of the decision matrix for determining which fourth-generation fighter to purchase:

- Air-to-air: air defense of land and sea and escort of friendly aircraft

- Air-to-ground: air interdiction, battlefield interdiction, and close air support

- Air-to-sea: function as part of air operations of naval forces

- Air reconnaissance support: above the ground and sea, including weather reconnaissance $^{22}$

Aircraft requirements included the ability to detect, track, and engage air targets in all weather and all visibility conditions. Additionally, the multi-role fighter aircraft was required to detect, track, and precisely engage ground and sea targets with both guided and unguided munitions, and to conduct reconnaissance with real-time transfer between optical, optical-electronic, and radio-electronic devices to ground command posts. ${ }^{23}$

As part of the technical analysis for each competing aircraft, Colonel Jan Błaszczyk of the Polish Air Force compared and evaluated the capabilities of the fighter aircraft according to various criteria. He used a relative scale to collate his results. Błaszczyk developed a composite score by weighting and combining the scores in each of the performance categories. In addition to the three competition aircraft, Błaszczyk included in his analysis three combat aircraft that were then being operated by the Polish Air Force: the MiG-29 Fulcrum A, the Su-22M4, and the MiG-21bis Fishbed N. He graded all the aircraft in the following categories:

- Technical/tactical parameters (air-air, air-ground)

- Ability to maneuver (air-air, air-ground)

- Armament (air-air, air-ground)

- Avionics (air-air, air-ground)

- Dynamic properties (overall)

- Battlefield survivability

- Electronic warfare/self-defense characteristics

- Operational cost (labor hours, maintenance requirement)

- Composite factor of all of the above. ${ }^{24}$

The F-16 ranked first in the air-to-air and air-to-ground mission areas of the avionics and armament categories, as well as the overall evaluation. The Mirage and the Gripen both ranked first in other categories. For instance, the Mirage excelled in electronic countermeasures and performance, while the Gripen had the lowest maintenance costs. All

22 Lech Konopka, Polish Military Aviation 1990-2003 (Warsaw: Dom Wydawniczy Bellona, 2003), 161-62.

23 Ibid.

24 Jan Blaszczyk, "Walory techniczno-bojowe samolotow wielozadaniowych F-16C, JAS 39 Gripen, Mirage 2000-5 a jakosc samolotow bojowych WLOP," Czese $i$ w numerze (March 2003). 
three aircraft ranked similarly in the majority of categories and represented a major upgrade from the MiG-29 Fulcrum A, the Su-22M4, and the MiG-21bis Fishbed N. The MiG-29 had a slightly lower ranking in the technical/ tactical parameters air-to-air category. However, its lack of armaments, electronic warfare capability, and high maintenance demands placed it significantly behind the other three aircraft in the overall assessment. The other two single-role aircraft ranked four to five times worse in their specialties according to the relative indicators. ${ }^{25}$

In addition to the F-16 coming out on top of Błaszczyk's technical assessments, Brigadier General Anatol Czaban noted that the F-16 was a good buy, with a great deal of combat experience. The F-16 was widely disseminated and purchased, with a total of twentyfour countries flying the F-16 and over 4,000 aircraft produced. He observed that the F-16 had been built and tested for many years from an operations, maintenance, logistics, and lifecycle perspective. Czaban felt the U.S. support in terms of access to training and F-16 experience was critical to preparing a relatively large number of pilots and mechanics in a short period of time. ${ }^{26} \mathrm{He}$ painted the F-16's competition in a less flattering light when discussing interoperability

Czaban felt commonality was important to fulfill Poland's role as a NATO ally. He viewed the aircraft itself as just a platform that must work as part of a system to receive and deliver information. In Czaban's opinion, the French and Swedish aircraft could not fully work within this information system, and therefore were not fully NATO interoperable. First and foremost, Poland needed fighter aircraft that met NATO standards, and the F-16 ensured Poland's NATO interoperability. ${ }^{27}$ Commenting on the sale, Mr. Bruce Lemkin, Deputy Undersecretary of the U.S. Air Force for International Affairs, stated, "these F-16s will provide the foundation of interoperability that will enable us to carry out operations as NATO and coalition partners." 28

The contracts and production capabilities for all three competitors ensured the delivered platform would be NATO interoperable, effectively taking the issue of interoperability out of the decision matrix. Additionally, as fourth-generation fighter aircraft, the performance and capabilities of the three fighter jets were relatively comparable. However, in the end, the F-16 eked out a win in the technical evaluation conducted in conjunction with the tender decision. With the F-16 having emerged victorious from a technical perspective, the Poles turned to negotiating favorable financing, overall contract price, and offsets with Lockheed Martin and the U.S. government, as well as the other competitors.

25 Ibid.

26 Anatol Czaban, Brigadier General, General Staff of Polish Armed Forces, Military Intelligence Directorate, Deputy Chief P-2, personal interview with author, George C. Marshall European Center for Security Studies, Garmisch, Germany, 5 September 2006.

28 Defense Security Cooperation Agency Press Release, "Ceremony Marks Rollout of First F-16s for Poland," 15 September 2006; available at www.dsca.osd.mil/PressReleases/by-date/2006/ 091506b.htm. 


\section{Financing and Price}

Although the F-16 was felt to be technically superior to its two competitors, it is important to recall that capabilities accounted for only forty out of the one hundred points assessed by the Tender Commission. The remaining sixty points were awarded based on price and offsets.

According to Janusz Zemke, Deputy Minister of Defense, the bid differentials between the three proposals were 10 percent or less. ${ }^{29}$ The unit procurement costs (cost of the latest production contract, excluding most research and development and support costs, divided by number of aircraft contracted) were not released by Poland, but, as a data point, the unit procurement cost for the JAS-39C Gripen was estimated at USD 68.9 million, including Value Added Tax. ${ }^{30}$ Colonel Peter Podbielski, of the U.S. Office of Defense Cooperation in Warsaw, further added that a matrix evaluating the price, platform capability, and weapons packages for the three aircraft yielded only a small variation. ${ }^{31}$ He recalled a less than USD 500 million difference in contract price between the highest and lowest bids. ${ }^{32}$ With a relatively small differential between the highest and lowest contract prices, competitors attempted to sweeten the deal with attractive financial terms.

The Bush Administration needed to be creative to overcome limitations imposed by existing U.S. government financing programs. Contrary to the European model, a competitive export credit facility to issue government loans or guarantees did not exist in the U.S., and the existing U.S. Export-Import Bank did not cover deals of the Polish F-16 flavor. The Defense Export Loan Guarantee (DELG), which was established in 1996 to provide the same function for military sales as the Export-Import Bank provided for other deals, was not competitive due to expensive financing terms. ${ }^{33}$ These limitations needed to be creatively overcome to make the F-16 offer competitive.

A work-around was discovered in Section 23 of the Arms Export Control Act that enabled the U.S. to extend a loan to Poland direct from the U.S. Treasury. This solution allowed the Defense Security Cooperation Agency to grant 100 percent of the loan, versus the 85 percent guarantee permitted under DELG. The permissible interest rate was based on the ten-year U.S. Treasury note instead of the market rate, making the financing much more attractive. In line with Poland's desire to defer principal payments until the outyears, the U.S. Congress authorized a very competitive fixed-rate thirteen-year loan with

29 "Offsets: The Big Payback," Warsaw Voice Online (5 January 2003); available at www.warsawvoice.pl/view/852/.

30 "Sticker Shock: Estimating the Real Cost of Modern Fighter Aircraft," Defense-aerospace.com (2006).

31 Colonel Peter Podbielski, Colonel, U.S. Army (retired), worked in the Office of Defense Cooperation at the U.S. Embassy in Warsaw during the period leading up to and following Poland's choice of the F-16.

32 Podbielski, e-mail message to author, 19 October 2006.

33 Peter C. Evans, "Appendix 13E. The Financing Factor in Arms Sales: The Role of Official Export Credits and Guarantees," Military Spending and Armaments (2002): 539. 
principal payments deferred for eight years. The U.S. interest rate was assessed to be close to 5 percent. $^{34}$

In addition, based on Congressional approval, DSCA significantly reduced financing fees and obtained a letter of credit from a commercial bank to serve as a performance bond, which facilitated Poland's ability to meet the default subsidy requirement. Lastly, as part of the offer, Poland was permitted to buy-down the loan by increasing its up-front payments, which essentially amounted to a "loan interest rate reduction fee." $"$ All in all, the creativity of the U.S. government's financing proposal made the F-16 offer more attractive.

Although details of the Gripen and Mirage financial packages are not accessible to the public, available information points to equally lucrative financial terms. The financial terms offered by the Gripen team included substantial government support and backing through the guarantee of export credit. A consortium of European banks allowed Sweden's Exportkreditnämnden and the United Kingdom's Export Credits Guarantee Department to jointly offer 100 percent coverage for fifteen-year loans at a competitive rate of 4.5 percent. The French government initially agreed to back 85 percent of the Mirage offer, but later agreed to back 100 percent of the financing terms at the low interest rate of 3.4 percent. ${ }^{36}$ With favorable financing lined up for all three offers, Poland's attention and priority turned to proposed offsets.

\section{Offsets}

To fully understand the role offsets played in the overall tender, a basic working knowledge of offsets, and Poland's expectations in terms of offsets, is required. "Offset-speak" is defined as follows for use in this analysis: ${ }^{37}$

- Offset Agreement: an agreement signed between the Minister of Economic Affairs on behalf of the State Treasury and the foreign supplier

- Foreign Supplier: a foreign contractor delivering weapons or military equipment

- Offsetor: a foreign supplier or an enterprise acting on behalf of this supplier in direct cooperation with an offsetee

- Offsetee: an offset receiver, to include Polish companies, universities, research and development centers (R\&D), or public sector entities

- Offset Commitment: the obligations of a foreign supplier (offsetor) towards an offsetee

- Direct Offset: offset commitments performed by defense industry companies, whose objective is production, repairs, servicing, research and development, and trading in armaments

34 Ryzsard Jaxa-Malakowski, "Proposals Issued for Poland's Fighter Contest," Flight International (19 November 2002); available at www.flightglobal.com/articles/2002/11/19/158029/proposalsissued-for-polands-fighter-contest.html.

Evans, "The Financing Factor in Arms Sales," 542.

Ibid., 539, footnote 3.

37 Podbielski, e-mail message to author, 18 October 2006. 
- Indirect Offset: offset commitments concerning any other companies registered in Poland.

Foreign contractors' attention was drawn to Poland's national preferences in the field of offset needs. ${ }^{38}$ However, Poland's offset law concerned prospective offsetors. Competitors expressed concerns over three main issues. First, the offset law forced foreign offsetors to direct most offset projects to existing and, at the time, unreformed Polish defense companies, with their inefficient cost structures and Soviet-style legacy management. Second, the Polish offset law did not completely comport with common international standards for offset procedures, practices, and regulations. Third, the penalty system for nonperformance of offset obligations was extremely punitive, with the penalties potentially exceeding 100 percent of the value of such obligations. ${ }^{39}$

The initial Request for Proposal (RFP) for the purchase of multi-role fighter aircraft was issued to the governments of France, Sweden, the U.K., and the U.S. The RFP identified a two-phased tender and called both for twenty-four new and twelve inventory (used) multi-role fighter aircraft, and an offset offer equal to the overall aircraft program value, i.e., 100 percent. ${ }^{40}$ In the RFP's second phase, Poland changed the specification from a combination of thirty-six new/inventory to forty-eight new aircraft, and retained the requirement for a 100 percent offset. The French, U.K./Swedish, and U.S. offset proposals each exceeded USD 10 billion as evaluated by the respective bidder. Unfortunately, very few details of the Dassault and Saab/BAE offset proposals are available because the Poles involved in the assessment and evaluation of offset proposals signed non-disclosure agreements. In addition, the Saab/BAE and Dassault teams, in conjunction with the Swedish, British, and French governments respectively, classified their programs and offset proposals. However, open-source articles do allow some insight into the proposals.

Total Dassault offset proposals were estimated at eighty-two specific offers, sixty-five of which were for defense and aerospace companies. As part of the proposals, Dassault offered final assembly of the Mirage 2000 at Mielec. It also proposed that Mielec and Swidnik be the exclusive suppliers of Mirage 2000 components and that Swidnik increase the number of components manufactured for the Falcon business jet and Rafale intakes. Dassault also offered to become a part of the Iryda/Iskra 2 program, and to flow work to the Hydral, WZL-2, Kalisz, and Rzeszow engine factories, specializing in hydraulics. ${ }^{41}$

Dassault assessed their proposed offsets at USD 3.8 billion, while Poland, according to Deputy Economy Minister Andrzej Szarawarski, determined the value after verification to be USD 2.1 billion. $^{42}$ It is difficult to determine how these numbers were arrived at with the limited information available. Speculatively, the numbers may have been reached by using multiplier factors, with the multiplier factors biased in favor of high-technology offsets. $^{43}$

${ }^{38}$ Podbielski, e-mail message to author, 18 October 2006.

39

40

Ibid.

${ }^{41}$ Penney, "Proposals Issued for Poland's Fighter Contest."

42 "Offsets: The Big Payback," Warsaw Voice Online.

${ }^{43}$ Glowacki and Sobzack, "Poland Opts for F-16s." 
The Swedish/British bid assessed the offset value at USD 7.48 billion, with the price of the bid at USD 3.15 billion. Following verification and application of the offset multiplier, Deputy Economy Minister Andrzej Szarawarski stated that Poland downgraded the value of the offer to USD 4.7 billion. ${ }^{44}$ The Polish assessment of the offset offer from Saab/BAE caused Björn Magnusson, Saab/BAE Polish operations chief, to comment, "We were very disappointed to see the American offset deal assessed as better than ours." $" 4$

The offset proposal submitted by Lockheed Martin was valued at USD 9.8 billion, ${ }^{46}$ with a bid of USD 3.58 billion for forty-eight F-16 C/D Block 52+ multi-role fighter aircraft. The operating principle was that Poland would select offsets from this offer that would equal the program value of the aircraft (USD 3.58 billion). On 21 January 2003, the Poles informed a combined U.S. and Lockheed Martin team that the new 100 percent offset requirement was USD 6.028 billion, the value that Poland reduced the offer to after verification and application of Polish Law offset multipliers. The offset became 170 percent of program value, and the largest in commercial history. Fully 61 percent of the offset proposal was approved by the Polish offset committee, for a total of 104 commitments, with 49 involving civilian sector indirect offset investments. ${ }^{47}$

The most pressing details were agreed to at 4 AM on 18 April 2003. The Foreign Military Sales case, the Foreign Military Financing loan, and the offset agreement were signed by noon. ${ }^{48}$ As significant as the offset agreement was to concluding the contract, economics were not the most important factor in the Poles' ultimate decision to purchase the F-16.

\section{Politics}

Shortly following Poland's announcement it would purchase the F-16, Charles Edelstenne, Dassault Chief Executive Officer, made it clear that he felt the choice of an American fighter over a European one was a political decision. Edelstenne noted, "The political element was the dominating element, much more than the quality of the material and the price. I felt for a very long time that they [Poland] very much favored rapprochement with the Americans. So, it's not a surprise." ${ }^{, 49}$ While not as vocal in their views, the Saab/BAE team also expressed disappointment in the ultimate decision. These sentiments pointed to an underlying current of discussion about the role of politics versus financing, offsets, and capabilities in the decision to purchase the F-16. The politics were framed in the context of European and U.S. relationships as they existed at the time.

On 27 December 2002, the day Poland announced its plans to purchase the F-16, Ambassador Hill, in commenting on the deal, stated, "It represents more than an airplane. It is

\footnotetext{
44 "Offsets: The Big Payback," Warsaw Voice Online.

45 Wojciech Kosc, "Poland Turns to U.S. for Fighter Jets," Transitions Online, Week in Review (24 December 2002 to 6 January 2003); available at www.tol.cz.

46 "Offsets: The Big Payback," Warsaw Voice Online.

47 Ibid.

48 Podbielski, e-mail message to author, 18 October 2006.

49 “U.S. Firm Wins Polish Jet Contract," BBC News World Edition (27 December 2002); available at http://news.bbc.co.uk/2/hi/business/2609169.stm.
} 
a fundamental choice about strategic political and military relationships." ${ }^{, 50}$ This statement, indeed, pointed toward the significance of politics. Kai Olaf Lang, a specialist on Central and Eastern Europe at the German Institute for International and Security Affairs, elaborated further:

The Polish political class sees the country's future as resting on two pillars: on a close relationship with the U.S. and the [EU's] Nice Treaty, which guarantees Poland almost the same voice in European affairs as France or Germany. Poles view the U.S. as the only realistic guarantee against something going wrong in Russia. The Nice Treaty, on the other hand, is their way of preventing Germany and France from controlling Europe. ${ }^{51}$

Poland's trepidation with respect to history, combined with a desire to play a more active role in NATO and European affairs, caused the country to make a strong relationship with the United States a cornerstone of their national security strategy. Commenting on Poland's relationship with the U.S., Poland's then Ambassador to the U.S., Przemyslaw Grudzinski, stated, "The development of Polish-American relations has been a priority for Polish governments since the collapse of Communism. Traditionally, relations are dominated by strong cooperation in international security. This reflects a convergence in the assessment of the challenges facing the international community as well as the shared values upon which the policies of both countries are built." ${ }^{, 52}$ In particular, Poland had been an ardent supporter of the U.S.-led operation in Iraq.

The closeness of the emergent U.S.-Polish relationship, the Poles' support of the U.S. role in the war in Iraq, and the sale of the F-16 to Poland were perhaps more than coincidental. When the U.S. looked to Europe to assemble a coalition of the willing to "liberate" Iraq, many of the nations of "old Europe" came out against the war. This dissent among traditional partners caused a transatlantic crisis that led the U.S. to look elsewhere in Europe for support. The U.S. found support, in particular, in Poland. The war in Iraq was used as a litmus test by the U.S. to determine who the U.S. could count on, with Great Britain, Italy, Spain, and Poland lining up behind the U.S., and Germany and France opposing the U.S. The decision to back the United States in Iraq, as well as the decision to purchase the F-16, had long-term implications for Poland. ${ }^{53}$

The near-term result of Poland's decision to support the U.S. was a meteoric rise in Poland's status as a partner. The alignment of Poland with Great Britain, Italy, and Spain in support of the U.S. assured Poland a significant voice in shaping fractured transatlantic relations and in the future look of the European model of political security. This stance also assured Poland's long-term stand on hotly debated issues, making the decision, in combination with the decision to buy the F-16, a decision to solidify Poland's place and

50 U.S. Diplomatic Mission to Warsaw, "Polish F-16 Roll-out Attended by Polish and U.S. Dignitaries," 18 September 2006; available at http://poland.usembassy.gov/poland/ f16_flight.html.

51 Michael Moran, "For Poles, the Choice was Easy," MSNBC.com (27 January 2004); available at www.msnbc.msn.com/id/4038199/print/1/displaymode/1098/.

52 Przemyslaw Grudzinski, "Poland's Accession to the European Union and Its Impact on United States-Polish Relations," Council of American Ambassadors, The Ambassadors Review (Fall 2004); available at www.americanambassadors.org.

53 Janusz Reiter, "Poland: Toward a More Perfect Union - or a Superpower Alliance?" The WorldPaper (May 2003); available at http://worldpaper.com/archive/2003/may_15/may2.html. 
influence for the next decade and to strengthen the Polish-American relationship. ${ }^{54}$ Poland was the only Eastern European nation involved in ground operations in Iraq, and its backing of the U.S., along with the eventual decision to buy the F-16 over the European bids, raised the ire of Poland's EU neighbors.

The above stated geo-strategic political considerations significantly influenced the Polish decision to purchase the F-16. According to one Polish commentator, ${ }^{55}$ "Lockheed Martin didn't win the contract, the U.S. government did, with pressure and support coming from the very highest levels. They created a program that, politically and economically, it was very hard to say no to." ${ }^{, 56}$ As New Republic senior editor John B. Judis speculated, the contract for the F-16 sale was tied to Poland's support in Iraq as a quid pro quo arrangement. ${ }^{57}$ Therefore, the sale is best viewed through a political lens, with the Polish commitment in Iraq being exchanged for U.S. investment in Poland.

Poland's support for the Iraq War, however, was not necessarily tied to the decision to buy the F-16. Although talks at the highest levels of both the U.S. and Polish governments on Iraq and the F-16 purchase occurred during approximately the same timeframe, there is no convincing evidence of Polish support for Iraq as a quid pro quo for U.S. investment in Poland via the F-16 deal. Poland was attempting to become more involved in the international community, and in particular to play a larger role in security affairs. As part of this desire to be more involved, according to Ambassador Grudzinski, "Poland consider[ed] participation in this operation as an investment in international security. Our contribution to the operation in Iraq also sends a strong message that Poland is a trustworthy and reliable ally and takes its international obligations seriously." 58 Poland's vision of being a more prominent international player, coupled with support for Iraq, naturally strengthened its ties with the U.S.

\section{Analysis and Conclusions}

Ultimately, the factors of operational capability, interoperability, economics, and politics must be weighed in terms of their respective significance to determine why Polish officials chose the F-16 over its competitors. Janusz Zemke, the Deputy Defense Minister and Tender Commission Chairman, has suggested that the decision was based 45 percent on price, 40 percent on tactical and operation criteria, and 15 percent on offsets. ${ }^{59}$ In addition to these criteria, Zemke expressed his satisfaction with the financial terms, but did not include the terms in the percentage breakdowns used by the Tender Commission to arrive at the final decision. While the percentages highlighted by Zemke may approximate the weight the Tender Commission assigned in deliberations, they do not tell the whole story.

In terms of operational capability and interoperability, there were relatively few differences between the three choices. The F-16, however, was the backbone of the NATO na-

\footnotetext{
54 Ibid.

"An Existentialist Shift: The F-16 Reaching Into Iraq," Dedefensa.org (11 June 2005); available at www.dedefensa.org/article.php?art_id=2137. Ibid.

57 Bollyn, "Why Eastern Europe Supported War."

58 Grudzinski, "Poland's Accession to the EU and Its Impact on U.S.-Polish Relations."

59 Simon, Poland and NATO, 135.
} 
tions' fighter aircraft inventory, with eight NATO nations flying the F-16 in 2002. The popularity of the F-16 within NATO may have played a role in Poland's selection. According to Jerzy Szmajdzinski, the choice was "an optimum solution for the military security of the state [that] meets our obligations as an ally." ${ }^{, 60}$ One Polish journalist, Pawel Wronski, supporting the fact that few capability differences existed between the three platforms, commented, "the Polish bid was unique in the sense that it saw a rivalry between three practically comparable aircraft that met our requirements. After all, neither the French Mirage 2000-5 nor the Gripen are inferior." ${ }^{61}$ Since all three aircraft provided the capabilities that Poland needed in a fourth-generation fighter, capability and interoperability considerations were not the major factors in the Polish decision.

Economics, however, played a larger role in the decision. Zemke stressed the importance of the economic aspects of the bids, stating that the "offset deals proposed were the key factor influencing the government's choice." ${ }^{62}$ Szmajdzinski reiterated Zemke's point, saying the jet order and offset agreement would "bring an economic and technological stimulus for Poland...." ${ }^{63}$ With economics playing such an important role in the final decision, the Dassault offer, assessed in real terms at around USD 2.1 billion, was far less competitive than the Saab/BAE and Lockheed Martin offers. In fact, as assessed, the Dassault offer did not meet the 100 percent requirement of the Polish offset law.

The offset offers from the two remaining teams were relatively comparable as assessed by the competitors themselves. Upon application of offset multipliers by the Poles, with additional weight presumably assigned to technical industries, the offers remained relatively comparable, at approximately USD 4.7 billion for the Saab/BAE offer and USD 6 billion for the Lockheed Martin offer. Financing terms were relatively comparable between the two offers as well, with the Gripen contract price slightly less than the F-16. Both offset offers guaranteed significant direct and indirect investment in Polish industry, and both assured the creation of significant numbers of jobs for Polish citizens.

The final figures of USD 4.7 billion versus USD 6.0 billion were less relevant, because the numbers could have gone either in favor of the Saab/BAE or Lockheed Martin team, depending on the Poles' assessment of the offer and the multiplier they used. Additionally, while large numbers (billions of dollars) were beneficial for the politicians to present to the Polish public, the numbers meant little until they came to fruition through actual investment and compliance with the offset agreement. With relatively comparable offers between Saab/BAE and Lockheed Martin from an economic perspective, the overriding factor in the decision was politics. Adding to the economic and technical benefits of purchasing the F-16, Szmajdzinski commented that the offset deal would "strengthen our links with the United States." 64

Politics played the predominant role in the Polish government's decision to buy the F16. Szmajdzinski attempted to counter this conclusion by stating the decision was based

60 Kosc, "Poland Turns to U.S. for Fighter Jets."

61 Pawel Wronski, "Planes and the Polish Cause," Warsaw Gazeta Wyborcza (28 December 2002), 3.

62 Kosc, "Poland Turns to U.S. for Fighter Jets."

63 Tagliabue, "Lockheed Wins Huge Sale."

64 Tagliabue, "Lockheed Wins Huge Sale." 
"on merit, not politics." 65 The facts support otherwise. The Poles were acutely aware of the suffering of their country during the twentieth century. Poland remained distrustful of Russia to the east, Belarus to the north, and Germany to the west. U.S. and NATO membership remained Poland's guarantee of continuing freedom from the dominance and yoke of Russia. The F-16 was representative of Poland's relationship with both the U.S. and NATO. Poland supported the U.S. policy toward Iraq, which created a schism between Warsaw and Paris at about the same time Poland was deciding which fighter aircraft to purchase.

Ultimately, according to Colonel Peter Podbielski, "the tender was ours [U.S.] to lose." ${ }^{, 66}$ Podbielski added that the Poles had privately relayed to the U.S. team that the proposal submitted in phase one of the tender bid was poor, notwithstanding the similarly low quality of the French and U.K./Swedish offers. The U.S. team heard the message loud and clear, and it became a catalyst for a more energetic response by the U.S. team in phase two of the bidding. Once a sizable offset package was in place to justify the sale to the Polish electorate, and this package was coupled with attractive and creative financing driven by politics at the highest level on the U.S. side, the final decision became a political one. ${ }^{67}$ Brigadier General Czaban supported this conclusion, noting that the final decision was a political decision, but also observing that, as a pilot, he agreed with the politicians. ${ }^{68}$

Kosc, "Poland Turns to U.S. for Fighter Jets."

${ }^{66}$ Podbielski, e-mail message to author, 19 October 2006.

67 Ibid.

${ }^{68}$ Czaban, personal interview with author. 


\section{THE QUARTERLY JOURNAL}

\section{Bibliography}

Blaszczyk, Jan. "Walory techniczno-bojowe samolotow wielozadaniowych F-16C, JAS 39 Gripen, Mirage 2000-5 a jakosc samolotow bojowych WLOP." Czese $i w$ numerze(2003).

Evans, Peter C.. "Appendix 13E. The Financing Factor in Arms Sales: The Role of Official Export Credits and Guarantees." Military Spending and Armaments (2002).

Glowacki, B., and G. Sobzack. Poland Opts for F-16s In Flug Revue ., 2003.

Grudzinski, Przemyslaw. "Poland's Accession to the European Union and Its Impact on United States-Polish Relations." Council of American Ambassadors, The Ambassadors Review (2004).

Konopka, Lech. Polish Military Aviation 1990-2003 In Warsaw: Dom Wydawniczy Bellona., 2003.

Malakowski, Jaxa. "Proposals Issued for Poland's Fighter Contest." Flight International(2002).

Michta, Andrew A.. "Modernizing the Polish Military." Defence Studies 2, no. 2 (2002): 44.

Moran, Michael. For Poles, the Choice was Easy. 27 January 2004, 2004.

Reiter, Janusz. "Poland: Toward a More Perfect Union - or a Superpower Alliance?" The World Paper (2003).

Simon, Jeffrey. Poland and NATO. Lanham, MD: Rowman \& Littlefield Publishers, Inc, 2004.

Wronski, Pawel. "Planes and the Polish Cause." Warsaw Gazeta Wyborcza (2002). 